\title{
Study on Importance of Communicative Competence and Its Cultivation in China's Context*
}

\author{
Caixia $\mathrm{Hu}$ \\ College of Arts \\ China University of Petroleum \\ Qingdao, China 266580
}

\begin{abstract}
Cultivation of communicative competence is of great importance in language teaching. This paper, beginning with the introduction of its concept, tries to illustrate the importance of communicative competence in language teaching and the practice of cultivating students' communicative competence in China's context.
\end{abstract}

Keywords-communicative competence; cultivation; language teaching

\section{INTRODUCTION}

It has been several decades since the appearance of the term "communicative competence" in the language teaching field. It is of great value to the language educators. It has drawn the attention of quite a lot of scholars, but no systematic illustration about its importance in language teaching has been made by now. This paper aims to systematically demonstrate its importance and language teachers' practice in China's context. It will be presented in three main parts: the concept of communicative competence, importance of its cultivation and its practice in China's context.

\section{CONCEPT OF COMMUNICATIVE COMPETENCE}

Communicative competence is a very important concept in the second language acquisition, but there's no uniform interpretation of the definition up to now. Here I'd like to present several models of the concept.

\section{A. Hymes' Model}

Communicative competence is a concept coined by Dell Hymes in 1966 against Noam Chomsky's distinction between linguistic competence and performance. Hymes (1966) defines communicative competence as what a speaker needs to know in order to be communicatively competent in a speech community. Lin (2004) gives further explanation, "Just like linguistic competence which tells you whether a sentence is grammatical or not, communicative competence tells you whether an utterance is appropriate or not within a situation."

\section{B. Canale and Swain's Model}

Canale and Swain (1980) define communicative

*Supported by the 12th Five-Year Planning Project in Science of Education in Shandong Province (YBW15017) competence in terms of four components: grammatical competence, sociolinguistic competence, discourse competence, and strategic competence. "Grammatical competence" lays emphasis mainly on the grammatical and lexical capacity. What words should be used? How to put them into phrases or sentences according to a series of rules? "Sociolinguistic competence" emphasizes the importance of context. It concerns how to appropriately use and respond to language in a given setting, as to a certain topic, based on the relationships among the people on the spot. What attitude should be picked up: courtesy, authority, friendliness or respect? And how can we predict the other's attitude when expressing? "Discourse competence" deals with the interpretation of a larger context and construction of coherent stretches of language. How to put the words, phrases, and sentences together to produce conversations, speeches? "Strategic competence" is about one's capability of using proper strategies to repair communication breakdowns and to make up for the language gap. What words should be said when misunderstanding occurs? How to make yourself understood when you don't know the exact expression of something?

\section{Faerch's Model}

Faerch (1984) points out 4 components of the communicative competence, i.e. linguistic competence, pragmatic competence, strategic competence and fluency. In his view, "linguistic competence" refers to phonological/orthographic, grammatical and lexical knowledge; "pragmatic competence" is the combination of linguistic competence and pragmatic and discourse knowledge; "strategic competence" is concerned about speakers' ability to use strategies to solve communication problems; and fluency refers to speakers' ability to clearly express themselves with ease. (Faerch et al,1984)

\section{Bachman's Model}

Bachman (1990) gives a definition containing two components: organizational competence (including grammatical and discourse/textual competence), and pragmatic competence (including both sociolinguistic and illocutionary competence). This view is much similar to that of Canale and Swain. 


\section{IMPORTANCE OF COMMUNICATIVE COMPETENCE}

The theory of communicative competence is quite useful in language teaching, for which we call Communicative Language Teaching. "Communicative Language Teaching (CLT) is the instructional framework for interaction. In CLT the instruction involves providing opportunities to interact in the target language. The goal is to gain competence in communicating in English. This means the learner is able to understand and interpret messages, understand the social contexts in which language is being used, apply the rules of grammar, and use strategies to keep communication from breaking down." (Savignon, 1997 in Moss 2005).

Cultivation of communicative competence is of great value in language teaching, it can be reflected in the following aspects: syllabus design, materials design, teaching training, teaching activities, etc.

\section{A. Syllabus Design}

In planning a language course, design has to be made about the content of the course, including vocabulary, grammar and skills used to teach in different levels. Communicative competence plays a very important role in syllabus design. There has been various communicative syllabus types in the history, such as "structural, functional, instrumental syllabus", "functional syllabus", "notional syllabus" and "task-based syllabus", etc. Here I'd like to highlight the "task-based syllabus", the most practical one. "Task-based syllabuses represent a particular realization of communicative language teaching. Instead of beginning the design process with lists of grammatical, functional-notional, and other items, the designer conducts a needs analysis which yields a list of the target tasks that the targeted learners will need to carry out in the 'real-world' outside the classroom." (Nunan, 2001)

There are some examples of the tasks:

- Preparing for job hunting, including CV writing, job interview, etc.

- Mailing a letter in a post office.

- Making an appointment through the telephone.

- Doing an application.

- Solving complaints of customers in a shop.

- $\ldots$

Centered on communicative competence, Syllabus designers realize that what should be emphasized in a syllabus is no longer the number of words students should grasp in different stages of learning, but the much more practical things.

\section{B. Material Design}

Focusing on the cultivation of students' communicative competence, many material designers are encouraged to provide a wide range of communicative materials, in the form of textbooks, audiovisual, computer display, etc. The materials have been shifted away from the boring inputting way. The primary goal of the materials is to present and practice content, to facilitate communication, and to aid students in practicing without the teacher, etc. The materials are more concerned about how the language is vividly presented in the classroom. They aim to increase students' motivation and involve them in interaction with the teacher. In communicative material design, the following roles should be considered:

- The materials will facilitate the communicative abilities of interpretation, expression, and negotiation.

- Materials will focus on understandable and relevant communication rather than on grammatical form.

- Materials will command the learners' interests and involve their intelligence and creativity.

- Materials will involve different types of text, and different media, which the participants can use to develop their competence through a variety of different activities and tasks. (Richards, 1985: 25)

There are many types of materials used in Communicative Language Teaching, such as text-based materials, task-based materials, authentic materials, and so on.

1) Text-based materials: The design of communicative materials has departed from that of previous language materials, which put emphasis on the grammatical and structural factors. It gives priority to the language practice. The reform of the Chinese listening textbooks can serve as a good example. Just from the change of its name can we see something. Before its name was "Students' Listening Book" while now it has been changed into "Listening and Speaking". More questions, more discussion topics, more dialogues and more activities have been added. Students have more chances to flexibly use what they have learned after listening. The interaction between teachers and students has been strengthened with the help of various means.

2) Task-based materials: There are varieties of materials available to cater to the task-based communicative needs, such as booklets, cards, and handbooks, etc. There are also some role plays, pair work, and games worked out to accommodate to the special teaching tasks. The end to foster the communicative competence plays a very important role in choosing task-based materials. These materials help to minimize the differences between the students' classroom learning and the knowledge acquisition in the real world, so that the students' problem-solving abilities can be developed with help of the task-based materials.

3) Authentic materials: "Nunan (1999) defines authentic materials as spoken or written language data that has been produced in the course of genuine communication, and not specifically written for purposes of language teaching." (Gail K. Oura, nd) A wide range of examples could be provided, including listening-viewing materials as shows 
and movies, visual materials as slides and photographs, printed materials as sports reports and newspaper, etc. These materials are very useful in Communicative Language Teaching. Gebhard (1996) sees authentic materials as a way to "contextualize" language learning. When lessons are centered on comprehending a menu or a TV weather report, students tend to focus more on content and meaning rather than the language itself. This offers students a valuable source of language input, so that they are not being exposed only to the language presented by the text and the teacher. (Gebhard in Gail K. Oura, nd)

\section{Teaching Training}

Teachers need training in the educational field, for the development of communicative syllabus design doesn't mean the teachers' complete understanding and mastery of the new thoughts, a coherent methodology may not be followed. The syllabus designers may provide the guidance, but it is the teachers who put it into practice in the classroom. As Rivers says (1968), "the effectiveness of any method in a particular situation is a function of the actual classroom performance of the individual teacher ."

Lots of the teaching arts and the teaching methodology in correspondence with the characteristics of the communicative language teaching should be taught to the teachers in the training program. How to lead and monitor the students' performance? And how can we evaluate their utterances? All these need skills. For some teachers, accepting such a teaching methodology means an almost complete change of their previous role in the classroom.

Moreover, the teaching training should be penetrated throughout the whole teaching process. Both pre-service and in-service training should be provided. For those who lack sophistication and much classroom experience, pre-service serves very well to help them properly handle the class. Inservice training "introduces the experienced teachers to the communicative materials and lets then discovers for them the new challenges." (Johnson and Porter, 1983: 138)

\section{Teaching Activities}

Teachers play an important role in organizing teaching activities. A variety of the activities are designed by the teachers to enrich the class.

1) Classroom activities: Classroom activities are the key link in the communicative language teaching chain. Apart from the activities prescribed in the teaching materials, the teachers should also provide some adaptable activities according to the class needs. Suggested Interactive Classroom Activities by Donna Moss (2005) are shown below:

- Information Gap - Two people share information to complete a task.

- Jigsaws - Learners pool their information to complete a task.
- Conversation Grid Activities - Practice gathering and giving the same information over and over again, thus helping to build automaticity

- Ordering and sorting activities, including classification, ranking and sequencing

- Problem-solving activities at all levels

- Discussions in which they practice any number of language development skills. (Donna Moss, 2005)

2) Teacher roles: Teacher roles should also be adapted to the Communicative Language Teaching. Several teacher roles described by Breen and Candlin (1980) are: 1) facilitating the communication process between all participants in the classroom 2) acting as an independent participant within the learning-teaching group 3) contribute both as a researcher and a learner" (Breen and Candlin in Richards 2001: 171)

In my opinion, the following roles should be performed by teachers:

- Creating the setting and introducing the activities.

- Making coherent links between activities.

- Providing topics when necessary and leading the discussion.

- Monitoring the group's performance. Giving constructive suggestions when necessary and trying to make it go smooth.

- Intervening and giving guidance in the individual's presentation before it goes too far away from the topic.

- Evaluating students' utterance. Pay attention to the use of commentary words and do not discourage them.

- Modifying materials according to the students' needs and the practical situations.

\section{COMMUNICATIVE COMPETENCE IN CHINA'S TEACHING CONTEXT}

With growing importance of the language use in the fastdeveloping society, communicative competence is undoubtedly seen as a goal for English Language learners in China. It can also be shown in the following aspects: official documents, syllabus, teaching training, and teaching materials, teaching activities, etc.

\section{A. Official Requirement}

The university students in China's context are required to pass CET4 (College English Test, Band 4), a test tends to encourage students' communicative competence development. Otherwise, they are not entitled to the bachelor's degree. As to CET6 (College English Test, Band 6 ), it is optional. But most students actually can pass it before graduation. 


\section{B. Syllabus}

According to the newly revised syllabus by Chinese Ministry of Education in 2017, the objective of College English teaching is: 培养学生的英语应用能力, 增强跨文化交际意 识和交际能力, 同时发展自主学习能力, 提高综合文化素养, 使他们 在学习、生活、社会交往和未来工作中能够有效地使用英语, 满足国 家、社会、学校和个人发展的需要。( To cultivate students' ability in using English, enhance their awareness of cultural communication and communicative competence; develop their ability in autonomous learning and comprehensive cultural ability, so as to make them effectively use English in study, life, social communication and future job, catering to the needs of the country, the society, the university and the individual.)[My translation] (Guidelines on College English Teaching, 2017) Cultivation of students' communicative competence has been clearly set as a goal in language teaching.

\section{Teaching Training}

Before teaching a course, the teachers have to attend the pre-service training in communicative language teaching, and during teaching process, the teachers also have chances to attend the in-service training. Besides, teachers of each department meet once a week to exchange experience and discuss the problems met both in books and in class. It has become a popular phenomenon for the teachers to frequently observing each other's class so as to absorb others' merits, avoid problems and meanwhile present others some constructive suggestions if possible. For any young teacher who first enters the teaching field, there must be an experienced teacher recommended as his adviser, from whom he can frequently seek help.

\section{Teaching Materials}

1) Textbooks: The teaching materials used in China are closely compatible with the syllabus which centers on the cultivation of students' communicative competence. To closely keep up with the dynamic communicative language teaching, the College English textbooks have been revised several times during the past years. More activities have been added and the texts have been changed into much useful ones to keep step with the development of the outside world. The preparation part of each unit usually involves varieties of activities closely related to the topic of the unit: gap bridging after listening to a short paragraph, storytelling by looking at a given picture, and psychology test, etc. During the presentation of cultural background information, usually both the audio and visual means are used. During delivery of the passage, lots of topics for discussion and questions to guide the students have been given. As to the exercises, they have been designed in various forms involving open discussion, listening practice, summary, retelling the story, translation, filling in the blanks, and short-paragraph writing, and so on. All these are used to enhance the interaction between students and the teacher.

2) Supplementary handouts and audio-visual materials: Apart from the textbooks, lots of handouts and audio-visual materials also serve well to fully cultivate students' communicative competence. Some other passages relating to the information of the text will be handed out to the students as their extensive reading and sometimes they will be checked. Sometimes they are asked to write a short paragraph based on their understanding, and sometimes they are required to give the main thoughts orally, sometimes to have a group discussion concerning this, or maybe a debate. Lots of the audio-visual materials serve as the assignment to consolidate what they have learned and dig more about the important expressions used by the characters inside, their way of behavior, and sometimes some morals. Music and news are often used as materials to help them learn in entertainment.

3) Materials used in the language lab: Lots of materials are available in the computers of language lab. In the university, the students usually have the time of "Autonomous Learning" every week. They can choose different materials according to their own needs. Various kinds of materials are available there, including written materials, listening materials, interpreting exercises, translation work and even self-test, etc. The students can also click somebody and do a group discussion. This is often used in the oral class under the monitoring of the teacher.

4) Other materials: Besides the materials mentioned above, there are also lots of online materials for the students to use on the website of our school. Students can receive the wireless broadcast of English program, and sometimes the listening materials they have covered in class anywhere on campus. More resources of materials will be developed for the students' use in future.

\section{E. Teaching Activities}

The main aim of teaching activities is to practice Communicative Language Teaching, but as to the types of activities, it may vary from individual to individual. However, there is also some commonness. Usually at the very beginning of the class, there will be some lead-in activities, providing a chance for the students to practice oral English. Sometimes, the students will be asked to come onto the stage and do a report with help of the PowerPoint they've made by themselves. After the presentation, a lot of questions will be hit on them. Through this activity, students could become much more courageous and motivated.

After a brief comment on the class presentation, teachers usually move to the introduction of the cultural and social background of the text in form of the questions, stories, pictures, or videos, etc. In dealing with the text, lots of activities can also be involved with help of the handouts and PPT, such as bridging the gap, group discussion, to name a few. The deep thinking question part usually serves as the oral work. Role plays, debate and imitation, etc. are also my frequently adopted in-class activities. To foster the students' listening ability and enrich their background information, additional listening exercises concerning the topic are often used. Moreover, music and news also serve the class well. 
The assignments are usually designed to cater to the development of the students' communicative competence, thus being checked in different ways, sometimes orally, sometimes in the written form.

However, there are also some problems in dealing with the activities. For example, the class in China's context is usually very big, so it's comparatively difficult to do the group work. It's difficult to involve all the students in the activities in the same period. With the growing emphasis put on the students' communicative competence, this situation will be hopefully improved in the nearest future.

\section{CONCLUSION}

Cultivation of communicative competence is of great importance in language teaching. Its importance can be seen from various aspects: syllabus design, material design, teaching training, teaching activities, etc. Based on the introduction of the concept of Communicative Competence, the paper highlights its importance in language teaching and efforts for its cultivation in China's context. Language teachers' practice in China has been introduced in such aspects as syllabus, teaching training, and teaching materials, teaching activities, etc.

\section{REFERENCES}

[1] Bachman, L. F. (1990) Fundamental Considerations in Language Testing. Oxford: Oxford University Press.

[2] Chinese Ministry of Education (2017). Guidelines on College English Teaching, http://wyx.hacz.edu.cn/s/17/t/85/d4/55/info54357.htm [Date accessed 10/11/17]

[3] Faerch C. , Harastrup K. and Phillipson . (1984) 'Learning Language and Language Learning”. Multibilingual Matters, pp. 167-181.

[4] Gail K. Oura (nd) 'Authentic Task-Based Materials: Bringing the Real World Into the Classroom'. http://www.jrc.sophia.ac.jp/kiyou/ki21/gaio.pdf [Date accessed $12 / 11 / 17]$

[5] Hymes, D.H. (1971). On communicative competence. Philadelphia: University of Pennsylvania Press. Extracts available in Brumfit, C.J. \& K. Johnson, (Eds.) (1979). The communicative approach to language teaching, pp. 5-26. Oxford: Oxford University Press.

[6] Johnson Keith (1983), Communicative Syllabus Design and Methodology. Exeter: Pergamon Press.

[7] Johnson K. and D. Porter (1983) Perspectives in Communicative Language Teaching America: Academic Press, INC.

[8] Lin Chienjer Charles (2004) ANTH276: Introduction to Anthropology: The Nature of Language. http://www.u.arizona.edu/ clin/anth276_04/anth276_handouts/HD3_ hymes.pdf [Date accessed 10/11/17]

[9] Moss Donna (2005) 'Teaching for Communicative Competence: Interaction in the Classroom'. Focus on Basics.

[10] Nunan David(2001), 'Aspects of Task-Based Syllabus Design'. Learning Teaching Hong Kong: University of Hong Kong. December.

[11] Richards, Jack C. (1985), The Context of Language Teaching. Cambridge: Cambridge University Press.

[12] Richards Jack C. and Theodore S. Rodgers (2001) (2nd edition) 'Communicative Language Teaching'.

[13] Approaches and Methods in Language Learning. Cambridge: Cambridge University Press.

[14] Rivers, W (1968). Teaching Foreign Language Skills Chicago: University of Chicago Press. 